\title{
ЯРМАРОЧНАЯ И БИРЖЕВАЯ ТОРГОВЛЯ ПРОДОВОЛЬСТВЕННЫМИ ТОВАРАМИ В ЦЕНТРАЛЬНО-ЕВРОПЕЙСКОЙ ЧАСТИ РОССИИ ВО ВТОРОЙ ПОЛОВИНЕ XIX - НАЧ. XX ВВ.
}

\section{FAIR AND EXCHANGE TRADE OF FOOD PRODUCTS IN THE CENTRAL EUROPEAN PART OF RUSSIA IN THE SECOND HALF OF THE XIX ${ }^{T H}-$ BEGINNING OF THE XX ${ }^{T H}$ CENTURIES}

S. Rogatko

Summary: This article analyzes the main factors contributing to development of fair and exchange trade of food products in the Central European part of Russia in the post-reform period. The characteristics of the main subjects of the grain fair and bazaar trade in the Volga region, as well as the fair food trade in the Chernozem provinces and other industrial regions are estimated. The statistics of all-Russian and regional fairs, emergence of food exchanges during the 19th century are investigated, the main factors, aspects and forms of exchange trading in large shopping centers, the interaction of authorities and business community within the framework of exchange trading, are analyzed, the main exchange mechanisms and forms of activity of industry exchange specializations are given a throughout analysis. The regulations on trade measures and weights are analyzed.

Keywords: fairs, food markets, grain trade, trade turnover, traders, stock exchanges, specialization in stock trading, food processing industries, entrepreneurs, industrialists.

\author{
Рогатко Сергей Александрович \\ К.и.н., Член Российского комитета по истории \\ и философии науки \\ и техники РАН, \\ rogatko1@yandex.ru
}

Аннотация: В данной статье анализируются основные факторы, способствующие развитию ярмарочной и биржевой торговли пищевыми товарами в Центрально-Европейской части России в пореформенный период. Дается характеристика основных субъектов хлебной ярмарочной и базарной торговли в Поволжье, а также ярмарочной продовольственной торговли в Черноземных губерниях и других промышленных районах. Исследуется статистика всероссийских и региональных ярмарок, возникновение продовольственных бирж на протяжении XIX в., приводятся основные факторы, аспекты и формы биржевой торговли в крупных торговых центрах, взаимодействие власти и предпринимательского сообщества в рамках биржевой торговли, анализируются основные биржевые механизмы и формы деятельности отраслевых биржевых специализаций, анализируется положение о торговых мерах и весах.

Ключевые слова: ярмарки, продовольственные рынки, хлебная торговля, торговые обороты, торговцы, биржи, специализация в биржевой торговле, пищеперерабатывающие отрасли, предприниматели, промышленники.

продовольственный рынок Центрально-Европейской часть России.

Хлебная торговля нижегородского Поволжья в 60-90-е гг.XIX В. делилась на три района: приречные торговые пункты, внутренние нагорные местности и заволжские населенные пункты. Среди приречных пунктов конечно же на первом месте считался сам Нижний Новгород. По сведениям губернского статистического комитета только в навигацию 1871 г. к нижегородской пристани было доставлено по Волге 11093307 пуд. и по Оке 160096 пуд. хлебных товаров - всего же 11253403 пуда.[1,С.48] А отправлено с нижегородской пристани по Волге 1377437 1⁄2 и по Оке - 2108 456, всего 3485893 1/2 пуда.[1, С.48] Всего же по сведениям местного начальника дистанции «всех родов товаров» на нижегородскую пристань в навигацию 1871 г. пришло 35.599363 1⁄2 пуд., 
а отправлено было 18452450 1/4 пуда.[1, С.48 (сноска)] То есть эти цифры говорят о том, что хлебная торговля в регионе играла первостепенную роль. В самое горячее время хлебной торговли в июне, июле и августе месяцах, совпадающих с ярмарочным временем в Нижний Новогород с саратовской, баронской, балаковской, самарской, хвалынской пристаней привозились в основном пшеница, мука-крупчатка, рожь, пшено и ячмень; с симбирской, казанской и камских пристаней, притягивающих хлеб из Вятской, Пермской, Уфимской губ. - ржаная мука, рожь, овес, гречневая крупа, горох и льняное семя. По мере приближения хлебных грузов к Волге цены на хлеб постепенно возрастали. Вот как выглядели цены на хлебные товары на пристани Нижнего Новогорода в 1871 г.: пшеница - 9-12 р. 60 коп. за четверть; мука ржаная - 65-70 коп.; овес - 3-3 р. 25 коп.; пшено - 9 р. 50 коп.- 10 р. 60 коп.; гречневая крупа - 7 р.-7 р. 50 коп. за четверть[1,C.50].

Кроме губернского центра среди приречных пунктов выделялись села Городец, Василева-Слобода, Лысково, Воротынец и др. Среди внутренних нагорных пунктов г. Арзамас, стоявший на втором месте по товарообороту после Нижнего Новгорода. В базарные дни на его рынке собиралось от 300 до 500 возов различных хлебных товаров. [1, С.98] Вообще, надо заметить, что в кругооборот хлебной торговли нижегородского Поволжья были вовлечены более 40 мелких городов, сел и деревень губернии, в которых существовали либо ежедневные базары, либо праздничные или базары определенных дней, как правило понедельника и пятницы. В свою очередь каждый торговый пункт специализировался более всего на своем определенном товаре. Например, в московские пекарни городецкая крупчатка специально шла для производства кренделей. Лысковская пристань преимущественно специализировалась на торговле ржаным хлебом разных сортов (сыромолотным, овинным, рижным и т.п.). Вся хлебная приволжская торговля в основном держалась на деятельности так называемых «подбегов» - мелких хлебных торговцев, которые покупали и перепродавали хлеб в селах и малых городах Поволжья. Не каждый крестьянин мог стать подбегом. Для этого ему необходимо было обладать некоторым денежным капиталом. Поэтому как правило подбеги выходили лица из зажиточных государственных крестьян или из наиболее удачных помещичьих крестьян сумевших получить подлинную свободу в результате реформ. Крупные торговцы закупали помещичий хлеб в зерне и продавали его из собственных или арендованных амбаров более мелким, «возовым». Те в свою очередь размалывали амбарный хлеб на окрестных мельницах и вывозили его в виде муки на базары приречных сел.

Как уже говорилось среди приречных сел во второй половине XIX в. по объемам товарооборота выделялось с. Лысково. В 1872 г. всего было привезено на Лы- сковскую пристань ржаной муки, ржи, льяного семени, пшеницы, овса, ячменя, а также крупы, гороха, солода и других переработанных товаров общим весом в 1514410 пуд. [1, С.62] Многие десятилетия в этом селе вся хлебная торговля была завязана на так называемых "прахах", сводчиках продавцов и покупателей. Это почти ругательное, обидное в те времена слово стало неким символом образа жизни и мышления многих сельчан. Они представляли из себя нечто в роде маяков, сельских кулаков, пушников и т.п. посредников старого торгового быта с той лишь разницей, что прахи не делали никаких закупок. Крупных прахов в 1860-80 -е гг. в Лысково было не более 10 человек [1, С.66]. Но зато мелких - чуть ли не в каждом доме. Они пускали продавцов в свой двор и брали на содержание их товар. В основном прахи специализировались по возовому, чувашскому, завалавскому хлебу (произведенному и привезенному из-за р. Валавы), и по помещичьему. Значение Лысково в нижегородской хлебной торговле было особенно велико в первую половину XIXв., когда суда двигались с помощью бурлацкой силы и хлеб доходил до С.-Петербурга через Рыбинск за два лета. Но с ускорением пути хлебных грузов из нижневолжских районов до Петербурга до 1 лета в 70-80-е годы за счет пароходного движения, значение лысковской пристани, как перевалочного пункта заметно снизилось. И уже камский, самарский и балаковский хлеб до конечных пунктов назначения доставлялся иногда за считанные недели, минуя или частично оставаясь в Лысково для последующей продажи его в заволжских, центрально-черноземных и других местностях. К концу XIX века лысковская торговля ввиду изменения торговой географии, главным образом хлебных продуктов из помещичьих экономий, и вовсе стала сокращаться.

Конкурентом лысковцев являлись хлебные торговцы на пристани в с. Воротынце. Там собирались покупатели, называемые «капиталами» или «суммами», приезжавшие из Городца, Твери («новаторы»), Ярославля и Петербурга. [1, С.77] Эти торговцы, как правило, вели крупно оптовую торговлю. «Суммы» подряжали «подсевал» - работников, которые просевали через решета и набивали кули или зерном или перемолотой на местных мельницах мукой, а также возчиков, отвозивших хлеб на пристанские амбары. Во время всех торговых операций в дело шло все. Даже пыль, остававшаяся от мешков «подсевалы» тщательно собирали и продавали хозяевам своих квартир. Одним словом, во многих населенных пунктах все было пропитано духом хлебной торговли, составлявшей для некоторых единственный источник к существованию.

Немаловажное значение в XIX в. не только в хлебной торговле, но и во всей продовольственной играла Нижегородская ярмарка. В 1816 г. после пожара гостиного двора на Макарьевской ярмарке (расположенной возле с. Лысково) в 1817 г. ее было решено перевести в Нижний Новгород в район Канавинской слободы. В первый 
же год существования Нижегородской ярмарки всех товаров по показаниям самих торгующих было привезено на сумму 26 млн. руб. сер, а к 1860 г. до 102 млн. руб. [2, С.90] По другим данным многие трактирщики построили «своекоштные трактиры», некоторые из которых в последствии переходили в разряд ресторанов. Появление Нижегородской ярмарки дало сильный толчок к развитию местного продовольственного предпринимательства. Если в 1820 г. в городе «стотысячником» ( купец, владеющий стотысячным и более капиталом - авт.) был лишь один купец из Арзамаса, торговавший во фруктовом ряду, то в 1839 г. их было уже 28, а в 1870 - 58.[3] О влиянии хлебной торговли на развитие Нижегородской ярмарки и всей местной предпринимательской деятельности говорит и такой факт, как привлечение в 1886 г. в комиссию по реконструкции Главного Дома ярмарки волжских хлебных магнатов Я.Е. Башкирова и Н.А. Бугрова, которые, кстати, не малые средства вкладывали вообще в строительство Нижнего Новгорода.[4. С.253-254]

Возросшие торговые обороты в погребных хозяйствах винодельческой продукции в столицах и других крупных городах в 1880 - 1890-е гг. способствовали появлению в этих промыслах появлению новой тенденции, проявившейся к этому времени. Русские виноделы и виноторговцы, поняли, что за XVIII - первую пол. XIX В. потребитель настолько успел привыкнуть к иностранному вину, что и от отечественного он стал требовать тех же качеств. Однако достигнуть подобного качества в русской винодельческой промышленности за такой период оказалось не так-то просто. Поэтому на смену качественным категориям пришли количественные. Торговцы для увеличения сбыта стали фабриковать русские вина по иностранным типам, а продавать дешевле, чем настоящее иностранное вино. Такое положение наблюдалось еще со времен Макарьевской, в последствии Нижегородской ярмарки, куда со всех винодельческих районов России стекался товар для подделки его под иностранные сорта вин. С Северного Кавказа доставлялось по дешевому водному пути недорогое молодое кизлярское вино (чихирь), которое московские и ярославские виноторговцы скупали и фабриковали из него дешевые сорта так называемых мадер, сотернов, жульенов и т.д. Донские казаки, которые привозили на ярмарку молодое вино, также продавали его виноторговцам, которые выделывали из него шипучее вино наподобие Цимлянского, хотя далеко уступавшее ему в качестве [5]. Лучшие южнобережные крымские вина под разными названиями продавались за французские, а вина керченские, бельбекские, альминские и судакские низкого качества сбывались за лучшие крымские. Среди торговцев особенно славились южнобережные вина как превосходный материал для купажа (смешения), и продавались они после прессования по 2-4 руб. за ведро. Выдержанное вино шло по 6-8 руб. за ведро, а ликерное вино из
Пино-Гри - по 3 руб. за бутылку [6, С. 83]. Слабые вина в бочках замораживались, а выморозки продавались на вес. Покупатель, делая из них вино, мог судить о качестве виноматериала по уровню замерзания жидкости, то есть, сколько спиртовых частей в объеме вина. В середине бочки собирался весь алкоголь, который, естественно, не замерзал. Именно эту жидкость продавали за известную «Мадеру».

Наибольшего торгового оборота Нижегородская ярмарка достигла в 1881 г. - 246 млн. руб. [7, С.323] В начале 90-х годов XIX в. в связи с широким развитием железнодорожных путей сообщения, кредитных и транспортных учреждений ярмарочная торговля стала терять свое значение, так как уже не было необходимости запасаться товаром на целый год, а можно было его приобрести по мере необходимости в любое время в местах производства. Так же отпала необходимость ездить на ярмарку для производства расчета и выбора товара, так как теперь этим стали заниматься банки, а выбрать товар можно было и по образцам. Однако теперь правительство и широкие промышленные и предпринимательские круги стали рассматривать Нижегородскую ярмарку, как важнейшую всероссийскую выставку для смотра всех отраслей экономики. Так в 1896 г. на Всероссийской промышленной и художественной выставке в Нижнем Новгороде в специальном IX разделе «Фабрично-заводской отдел. Производства питательных веществ» из всех 10500 выставочных экспонатов около 1500 были представлены производителями таких товаров, как мука, крахмал, сахарная патока, декстрит, макароны, сахар, различные консервы (специально для продовольствия армии), чай, а также товарами винокуренного и водочного производства.[8,C.1-2] Таким образом Нижегородская выставка-ярмарка, наряду со Всероссийской Московской выставкой становилась тем мерилом развития всей пищевой промышленности России, которая все больше и больше заявляла о себе, как наиболее важная во всей экономики страны.

Особое значение среди региональной продовольственной торговли во второй половине XIX в. имела ярмарочная торговля в Центрально-Черноземном районе. Только в одной Курской губ. в 1861 г. действовало 356 ярмарок, которые охватывали 117 населенных пунктов или 3,7 \% всех поселений губернии. [9, С.102] Из всего количества ярмарок 287 являлись сельскими и составляли 81 \% от общего количества. На каждое сельское поселение с ярмарочной торговлей в среднем приходилось по 2,9 ярмарки [9, С.104]. Отдельно в центральном Черноземье выделялась Коренная ярмарка, имевшая не только местное значение, но и всероссийское. Ее проведение приурочивалось к торжественному переносу из Курска в Коренную пустынь и обратно иконы Божией Матери. В девятую пятницу по Пасхе и 8 сентября в Коренной устраивалась ярмарка, где собиралось множество рос- 
сийских и заграничных купцов и торговцев. В 1861 ее товарооборот составлял 3684505 руб., а в 1864 г. уже 4605 320 руб.[10,C.81] Однако с открытием в губернии железной дороги, соединившей разные экономические районы и упростившей доставку сырья и в том числе сельскохозяйственного в крупные промышленные центры и готовой продукции потребителям, обороты ярмарки сократились. В 1876 г. на ней было продано товаров только на 1327000 руб. [10, С.81] В 1877 г. ярмарку перевели в Курск, где она окончательно потеряло свое было значение. Самый низкий ее оборот пришелся на 1892 г., составивший всего лишь 390300 руб. [10, С.81-82] Если крупные ярмарки во второй половине XIX в. имели тенденцию к трансформированию их либо в центральные городские ярмарки местного значения, либо в отраслевые и межотраслевые выставки, то местные сельские ярмарки оставались по прежнему актуальными рынками особенно что касалось всех категорий сельхоз производителей. Податные инспектора, описывая ярмарочную торговлю, отмечали тот факт, что «все они (ярмарки авт.) продолжаясь каждая не более суток, носят характер больших базаров с продажей разного рода товаров, скота и сельских продуктов». [10, С.82] Если на сельских ярмарках и базарах продавалось одновременно все: от сельскохозяйственных продуктов до кустарных изделий, то в крупных городах происходила специализация и товарная спецификация отдельных базаров. Например, в Курске приобрести съестные продукты можно было только на площадях Гостиной, Сергиевской и Навозной. В городах базары служили самым демократичным способом снабжения жителей дешевыми продуктами питания из первых рук. Главное же значение сельских базаров состояло в удовлетворении первичных товарных потребностей населения в период между проведением ярмарок. Особое место в пореформенной торговле пищевыми продуктами и сельскохозяйственным сырьем занимали торговцы-посредники, прасолы, или в некоторых местах их называли «шибаи», деятельность которых охватывала всю Россию. В хлебно-мукомольной, мясной, молочной, рыбной и других отраслях прасолы являлись основными звеньями между производителями и переработчиками. Однако по мере возрастания роли фабрично-заводского крупного производства в пищевых отраслях прасолы уступали свои функции производителям с их многочисленной армией агентов. Впрочем в таких отраслях, как мясная, птицеводческая и рыбная прасолы играли существенную роль вплоть до 1917 г. Так, среди крестьян Корочанского уезда Курской губ. наибольшее распространение получила скупка яиц для местных крупных купцов, которые в конце XIX в. «отсюда ежегодно отправляют в Москву миллионы яиц», поступающих «там частью на рынок, частью на альбуминные заводы».[11,С.92] К 1899 г. на этот промысел выезжало ранней весной «около 2450 телег» мелких торговцев, направляясь преимущественно в Новороссию и Пред- кавказье. [11, С.92] До октября такой скупщик совершал в среднем 26 поездок, привозя за каждую «ездку» до 7 тыс. яиц, сдаваемых 40 крупным торговцам, которые еще зимой выдавали «возчикам» под работу «задаток». За весь сезон скупки яиц в 7-8 месяцев подобный разъездной торговец - фактически наемный работник у крупного прасола - имел «чистого» дохода до 120 руб. [11, С.92]. К 1914 г. число мелких скупщиков в Корочанском уезде сократилась до 1196 чел., а их заработок упал до 80 руб. $[11$, C.92]. Подобная торговля была налажена и в Тамбовской губ, где к началу XX столетия только через железнодорожную станцию г. Козлова вывозилось ежегодно до 5 млн.. яиц из южной части Тамбовщины и соседних Воронежской и Донской области. [11, С.92] Ведущее место в птицеводстве и скупке яиц занимал английский предприниматель Р. Барсельман.

Всего по переписи 1894 г. в Европейской России насчитывалось 14048 ярмарки местного и всероссийского значения, помимо 1877 ярмарок в Привислянском крае. [7, С.324] По экономическим районам они распределялись следующим образом: в Московском районе - 2052, центрально-промышленном (в среднем земледельческом) - 2103, в Балтийском ( С.- Петербург) - 1405, в Северном - 362, Северо-Западном - 1556. Остальные приходились на Украину, Юг России, Восточные районы и Юго-Западный районы [7, С.324].

Для более эффективного взаимодействия всех категорий торговцев и посредников между собой в течении всего XIX в. наряду со столицами в крупных торговых центрах Центрально-Европейской части России образовывались биржи для оптовой торговли товарами, в том числе пищевыми или фондами (акциями) предприятий. Так в 1816 г. появилась биржа в Варшаве, затем в Москве (1817) [12,С.30], в 1842 г. появилась биржа в Рыбинске, в 1866 г. в Туле, Риге и Казани, в 1867 г. в Ростове-на-Дону, в 1869 г. в Самаре, в 1872 г. в Ревеле и Варшаве, в 1874 г. в Пернове, в 1877 г. в Орле, Либаве и Нижнем Новгороде, в 1888 г. в Ельце и Таганроге, в 1898 г. в Лодзи [7,С.324]. В некоторых городах для потребностей местных рынков устраивались специализированные продовольственные биржи, главным образом хлебные, так как Россия в этот период считалась одним из основных производителей и экспортёров зерновых продуктов. Например, по примеру 1895 г. в С.-Петербурга (1895) и Москвы (1896 г.) в 1897 г. в Воронеже также была устроена хлебная биржа [7, С.324]. Всего к началу Первой мировой войны в России действовало более 90 бирж [12, С.30]. Благодаря деятельности Особого Совещания о нуждах сельскохозяйственной промышленности 1902-1905 гг. и своевременной записке Министерства финансов, представленной на Совещание в феврале-апреле 1903 г., особо остро встал вопрос о переводе хлебной торговли и других видов переработанных сельскохозяйственных продуктов из «уходящей» ярмарочной торговли к новым формам, 
биржевым[13,С.26-27]. В начале XX в. в Поволжском регионе три биржи специализировались на торговле хлебом: Балаковская, Балашовская и Покровская. По товарообороту пшеницы Самарская биржа была крупнейшей во всей Европейской России (на 1913 г. обороты хлеба составили 18,7 млн. пуд, в том числе с пшеницей - 10,2 млн. пуд), далее шла биржа Покровской слободы и Балаковская. $[14$, С.25,145,147; 15, С.58] При биржах открывались собственные казначейства. Экономист Метт Б.А., характеризуя хлебную торговлю в начале XX в., главную задачу предпринимательского сообщества в этом направлении определял, как «увеличение числа хлебных бирж и живое общение между собою биржевых деятелей, в лице представителей главнейших групп хлебной торговли мукомолов, экспортеров и внутренних комиссионных торговцев хлебом» [16,С.35]. Одной из ведущих хлебных бирж в тот период считалась Калашниковская, основанная в Петербурге в 1895 г. [17, С.127] Здесь в 70-90-е гг. в Барановской гостинице «Биржа» торговали хлебом для нужд города и окрестностей, а также оформлялись поставки в Финляндию. Сделки с экспортным хлебом производились на бирже Васильевского острова. Также хлебной торговлей на биржах Петербурга занимались в гостинице «Византия» (по Гончарной улице), где собирались бежецкие, тверские, старорусские и другие хлеботорговцы для продажи овса, привозимого ими по Вышневолоцкой системе и железным дорогам.[18, С.5] В Барановской гостинице покупали и продавали только городской товар с помощью биржевых «маклеров»: муку ржаную и пшеничную, овес, горох и пшено. Маклеров как правило выбирали на общем собрании торгующих купцов, которое должно было «состоять не менее, как из одной трети всего торгующего при здешнем порте купечества» [19]. Также наиболее образованные хлеботорговцы выступали за то, чтобы иметь орган вроде биржевого Комитета, который бы следил за «непроизводством на бирже незаконного маклерства» и всячески способствовал «отстранении неудобств, проистекающих от каких-либо распоряжений или узаконений по части хлебной торговли и промышленности». Однако большинство же купцов «не сочувственно» относились к этим пожеланиям, т.к. хотели оставаться свободными от чьей-либо воли на бирже. [18.С.11]. Как правило цены на хлебных биржах Петербурга завесили: 1) от состояния портовых и иностранных рынков; 2) колебания на финансовом рынке; 3) перспективы на урожай в поволжских и других хлеборобных губерниях; 4) степень обеспечения продовольствием и урожай в Финляндии и прибалтийских губерниях. По большому же счету цены на хлеб весьма сильно зависели еще и от урожая «на всемирном рынке» $[20$, C.85].

Так же в начале XX в. действовали специализированные продовольственные биржи: масляные, мясные и скотопромышленные, курятно-дичные, яичные, фрук- товые, чайные, винные. Так в С.-Петербурге на ряду со скотопромышленной и мясной Биржами в 1906 г. была открыта яичная и масляная Биржа для торговли яйцами, маслом и другими молочными продуктами. При бирже действовали арбитражная, экспертов и котировальная комиссии. Биржа имела также отделение в Риге. [21, С.37] В Москве был создан специальный Биржевой комитет Московской биржи пищевых продуктов и вин. [22, С.30] По мнению некоторых исследователей, биржевые комитеты играли консолидирующую роль в торгово-промышленных кругах. Благодаря их деятельности создавались современные товарные склады, элеваторы, холодильники. Через свои «бюллетени», которые публиковали биржевые сводки или новости дня, биржевые комитеты, по сути дела, определяли рыночные ценовые механизмы. Появлялись различного рода издания торговой статистики, развивалось коммерческое и сельскохозяйственное образование. Российский историк Галаган А.А. отмечал, что «помимо основной функции (рынок), российская биржа играла роль представительного учреждения буржуазии, так как в России никогда не было такого учреждения, как Торгово-промышленная палата, которая призвана играть роль посредника между правительством и третьим сословием».[12,С.30] Впрочем, многие купцы и промышленники весьма неодобрительно относились к биржевой деятельности, и главным образом из-за царивших там «стандартных» товаров, особенно новинок одобренных предварительно предпринимательским сообществом. Так, например, крупнейший ростовский хлебный торговец Парамонов Е.Т. предпочитал оформлять торговые сделки минуя биржевое посредничество [12, С.31]. В трактирах и ресторанах заключали свои сделки крупные волжские мукомолы: Бугровы, Башкировы, Дегтярёвы и многие другие.

Для упорядочения оптовой и розничной торговли, в том числе продовольственной 4 июня 1899 г. было издано положение о мерах и весах, которое вводилось с 1 января 1900 г.[23] Центральным учреждением для поверки мер и весов служила главная палата в С.-Петербурге, в других городах были открыты подчиненные ей местные палатки, которые имели точные выверенные прототипы основных российских мер с указанием их соотношения с метрическими мерами. Однако все это не имело обязательного характера в торговли. И в реальной жизни еще долгое время практиковалось употребление метрической системы по взаимному согласию, что в свою очередь затрудняло расчеты между купцами и предпринимателями в разных районах не только ЦентральноЕвропейской части России, но в других экономических районах Российской империи.

Таким образом можно сделать вывод, что ярмарочная торговля в крупных масштабах в Центрально-Европейской части России во второй половине XIX - нач. XX вв. развивалась именно там, где к тому были сельскохозяй- 
ственные производственные и торговые предпосылки, особенно благодаря помещичьих экономиях, где были развиты центры переработки сельскохозяйственного типа - мукомольные, винокуренные, свеклосахарные и крахмально-паточные предприятия. Достаточно ярким примером тому может служить ярморочная и базарная торговля хлебными товарами (зерном, мукой и отрубями) в Поволжском районе. Также наиболее важными субъектами продовольственной ярморочной торговли можно считать ярмарки и торжки в Черноземных губерниях и прилегающих к ним районах. Что касается биржевой торговли, то она стала появляться в середине XIX в. В центрах хлебной торговли, а также в конце XIX в. в столи- цах и крупных городах в связи с ростом промышленного городского пищеперабатывающего производства. Биржи являлись своего рода концентрацией предпринимательской детальности и в том числе по отраслевым признакам. Продовольственная специализация биржевой деятельности, не взирая на различные экономические и социальные издержки, отражала реальную расстановку производственных и торговых сил на российском рынке. Главное отличие биржевой деятельности от ярмарочной было не только в конкретной организации торговли, но и в непосредственном отношении самих предпринимателей к формам, институциям и механизмам этой торговли.

\section{ЛИТЕРАТУРА}

1. ацисский А.С. Материалы для изучения хлебной производительности и хлебной торговли нижегородской губернии. // Нижегородский сборник. Т.5. Н.Новгород., 1875.

2. Богородицкая Н.А. Влияние нижегородской ярмарки на социально-экономическое развитие Ниежгородской губернии в первой половине XIX века. // Материальная и духовная культура феодальной России (Межвузовский сборник). Горький, 1990.

3. Алфавитный указатель лиц, торгующих на Нижегородской ярмарке 1870 г. Нижний Новгород. 1870.

4. Макарова Н.В. Предпринимательская деятельность купечества на Нижегородкой ярмарке в конце XIX в. // Факторы становления социального облика молодого российского предпринимателя. Н.Новгород.1995.

5. Небольсин. Коммерческая газета. 1847. № 136. (18 ноября)

6. Производительные силы России. Краткая характеристика различных отраслей труда — соответственно классификация выставки. Отдел IX. Фабричнозаводские производства. Виноделие. (Составил А.И. Базаров) СПб., 1896. С. 83.

7. Россия. Энциклопедический словарь, начатый проф. И.Е. Андриевским, продолжается под ред. К.К. Арсеньева и засл. проф. Ф.Ф. Петрушевского. (Репринт. изд.). Лениздат. Л.,1991.

8. Нижегородская выставка. ІХ отдел. Фабрично-заводской отдел. Производство питательных веществ. Доклад инженера-технолога Н.П. Мельникова в Одесском Отделении Импер. Технического Общества. (Отдельный оттиск из Записок Одесского Отд. Импера. Рус. Технич. Общества за 1897.$)$ 0десса, 1897.

9. Плаксин И.М. География ярморочной торговли Курской губернии в середине XIX столетия. // Курский государственный педагогический институт. Проблемы исторической демографии и исторической географии Центрального Черноземья. М.- Курск.1994.

10. Плаксин И.М. Структура Курского рынка в пореформенный период (1861-1899 гг.) // Торговля Курского края с древнейших времен до начала XX века. Курск.1996.

11. Курцев А.Н. Торговые миграции населения России во второй половине XIX-начале XX столетия (на примере Центрально-Черноземного региона) // Торговля Курского края с древнейших времен до начала XX века. Курск. 1996.

12. Галаган А.А. История предпринимательства Российского. От купца до банкира. М., 1997.

13. Всеподданнейший Отчет по особому Совещанию о нуждах сельскохозяйственной промышленности. 1902-1904 гг. СПб,1904.

14. За два года. Очерки общественно-экономической жизни Самарской биржи.1913-1914 гг. Самара.1915.

15. Самарская биржа. Биржевой ком. За двадцать лет: Юбил. сб. очерков деятельности Самар. бирж. ком. и 0-ва с 1893 по 1913 г.: С прил. бух. отчета за 1912/13 г. - Самара, 1914.

16. Метт Б.А. Хлебная торговля и подвоз хлеба, как продовольственные меры. Одесса, 1907.

17. Кузьмичев А.Д., И.Н. Шапкин. Отечественное предпринимательство. (Очерки истории). М., 1995.

18. Козловский А.Н. Хлебная торговля в С.- Петербургском порту. СПб., 1888.

19. Полное собрание законов Российской империи (ПСЗ-3 РИ). Т.XXXIX. № 41014. Июня 29 (1864) Высоч. Утв. Мнение Государ. Совета. - 06 изменении порядка выбора Маклеров при С.-Петербургском порте.

20. Бахтиаров А.А. Брюхо Петербурга (Очерки столичной жизни). СПб.,1994.

21. Отчет С.-Петербургской яичной и масляной биржи за 1906 г. СПб.,1906.

22. Поткина И.В. Деловая Москва. (Очерки по истории предпринимательства). М., 1997.

23. ПСЗ-3 РИ. Т.ХІХ. ч.1. №17056. - Июня 4. Высочайше утв. Положение о мерах и весах. - Мнение Государственного совета, Высочайше утв. 4 Июня 1899 года (Собр.Узак., 1899 г. Августа 5, ст.1322) 